\title{
Fake News, Forgery, and Falsification: Western Responses to Soviet Disinformation in Cold War India
}

\author{
Paul M. McGarr \\ Department of American and Canadian Studies, \\ University of Nottingham
}

Paul.mcgarr@nottingham.ac.uk

In the spring of 1967, Chester Bowles, the United States' Ambassador in India, launched a blistering public attack on the intensification within the subcontinent of 'a carefully calculated, massively financed campaign' of Communist black propaganda, or information designed to create the impression that it was produced by those it was intended to discredit. Bowles' stinging denunciation was carried on the front-page of the American Reporter, a bi-weekly publication distributed free of charge throughout the country by the United States Information Agency (USIA), and widely reproduced by Indian wire services. The Ambassador claimed that 'week after week' India's Communist press had printed 'a whole series of devious editorials and concocted "'news" stories' designed to discredit himself, his Embassy, and the wider United States government. The 'utterly false' allegations in circulation, the Ambassador noted, included accusations that America was covertly recycling funds from the sale of agricultural commodities to finance right-wing Indian politicians, and employing young volunteers attached to the Peace Corps programme as 'spies and saboteurs.' Bowles took particular exception to the reproduction of a series of forged documents that purportedly originated from official British and American sources, and that were 'carefully calculated to harm the U.S. efforts to assist Indian development.' The Ambassador called out the Communist press for indulging in 'international character assassination' which, by targeting a nation rather than specific individuals, circumvented India's libel laws. In the circumstances, Bowles proclaimed, 'there is no recourse except a bold airing of the facts, so that the public can know and judge the full story.' 1

The importance of nonaligned nations and, India, more especially, in the story of Western responses to Soviet Cold War disinformation operations has been elided by an inclination on the part of historians and political scientists to frame issues surrounding black propaganda in an East-West paradigm. ${ }^{2}$ As early as 1961, one recently declassified Central Intelligence Agency (CIA) study suggested that public attention needed to be directed towards covert propaganda practiced by Sino-Soviet Bloc intelligence services beyond Europe and North America. ${ }^{3}$ Such calls for a geographic rebalancing in studies appraising Soviet black propaganda campaigns went largely unheeded. What focus has been placed on disinformation campaigns inside the developing world has hinged on perspectives derived from Western and Soviet sources and has downplayed, or ignored, the responses and agency of Asian and African actors. $^{4}$

This article shifts the axis of the Cold War to examine the wider diplomatic impact of British and American reactions to covert Soviet propaganda and forgery operations from a NorthSouth standpoint. As one CIA report on Soviet clandestine subversive activity emphasized in the late 1950s, the promotion of communist ideology 'was not an essential factor in these [black propaganda] operations.' Their objective was invariably, 'to compromise, discredit, and ultimately destroy the governments, organisations and individuals most likely to block the increase of Communist and Bloc power in the area concerned...' That said, the United States 
was not above conducting disinformation-by-forgery. In 1953, one notable operation saw the CIA disseminate a fictitious autobiography of the pro-Soviet Iranian émigré poet, Abulqasim Lahuti. Packed full of criticism of Moscow's policies towards Soviet Central Asian Republics and the wider Middle East, the CIA ruse backfired and succeeded only in bolstering Lahuti's standing in the USSR, empowering him to push for a moderation in Stalinist repression of Persian and Tajik culture. ${ }^{5}$

Equally, British intelligence indulged in what came to be known as special political action (SPA), or activity that encompassed bribery, forgery, and covert funding of political parties. In the summer of 1960, in preparation for a meeting intended to co-ordinate information operations with American colleagues, British officials discussed plans for black propaganda work, including the use of forgery. In suggesting that Britain 'take the lead' in this area, Whitehall revealed not only a willingness to engage in disinformation-by-forgery, but also the perception that British covert propagandists were especially proficient in such matters and had a thing or two to teach the Americans. In detailing forgery operations mounted against international trade union organisations with communist connections, including the World Federation of Trade Unions, British official enthused that 'we should not hesitate to draw a bow at a [forgery] venture' that offered 'suitable targets'. 'Even if it [a forgery] achieves nothing else,' the British concluded pragmatically, 'the [ensuing] investigation by the communists has its own disruptive effects. ${ }^{6}$ As will become evident, India was not immune from British SPA. In many respects, non-aligned India offered an ideal environment in which to conduct black propaganda. An open democracy, with a large, free, and vibrant press, and a population broadly opposed to entering into Cold War alliances of any ideological stripe, India offered ample, 'cover for covert political action operations directed towards the manipulation of groups not otherwise susceptible to... manipulation." 7

The article also reperiodizes the study of Cold War disinformation activity. An emphasis has been placed on early Cold War propaganda in intelligence literature. Likewise, considerable attention has been devoted to espionage and covert action that occurred near the end of the Cold War period, at a time when East-West détente withered, and Washington's relations with Moscow soured following the 1979 Soviet invasion of Afghanistan, and the onset of Ronald Reagan's administration in the United States. ${ }^{8}$ Much less consideration has been given to the impact of Cold War covert propaganda in the context of decolonization inside the global South. Such activity on the part of the USSR, US and the UK complicated a commitment to non-alignment made by countries such as India. ${ }^{9}$ In addition, it acted as a source of friction in relations between the Soviet Union, the United States and Great Britain, at a point when all three countries were seeking to fashion more constructive ties following the Cuban Missile Crisis. Over the course of a decade, that began with the outbreak of the Sino-Indian border war in 1962, and culminated in the Indo-Pakistan conflict of 1971, India steadily disengaged from the West and tilted towards the Eastern bloc. In the process, New Delhi struggled to control diplomatic fallout from a covert propaganda war waged on its territory by the superpowers that, at times, appeared to imperil a reorientation of India's foreign policy.

Intelligence historians have noted elsewhere that Soviet intelligence activity in the decolonizing world invariably targeted the United States, as the Kremlin became progressively dismissive of British post-war power. ${ }^{10}$ India, as we shall see, represented an exception to this rule. Well into the 1960s, Moscow continued to direct major disinformation operations at vestiges of residual British power in the subcontinent. In so doing, the Soviet Union strove to diminish Whitehall's sway with the Indian political and economic establishment and, by closely associating UK regional policy with that of its American ally, undermine wider Western influence in South Asia. The importance that the Kremlin hierarchy attached to such activity, and the close bureaucratic scrutiny under which it operated, was underlined in a contemporary CIA assessment. 'Black propaganda is a function of the Bloc foreign intelligence services 
under close direction from high Party echelons,' American intelligence analysts concluded in 1961. 'It is possible that the entire Bloc show is directed by a unit of the CPSU Central Committee and run by the KGB through its liaison officers with other services. ${ }^{11}$

It is important to note that restrictions imposed by sovereign states on the declassification of intelligence records and, most especially, restrictions operating in contemporary Russia, make the sourcing of evidence in respect of foreign intelligence activity especially challenging. Conclusions derived from such material which, even when publicly disclosed, has first been subject to 'weeding', or selective curation by agents of the state, are necessarily contingent. In recent years, historians and political scientists have extended our understanding of post-war British covert operations. ${ }^{12}$ This work has added to the voluminous coverage previously given to American Cold War intelligence work. ${ }^{13}$ In contrast, official documents covering Soviet-era covert operations, and especially those conducted in the context of India, remain largely beyond the reach of researchers. ${ }^{14}$ Consequentially, much of the analysis of Soviet disinformation campaigns that follows is informed by British and American primary material. That said, an essential methodological leap in intelligence studies requires that material from the global South is linked to that from the Europe and North America to provide a more holistic picture of the impact and perceptions of British (and American) intelligence operations outside the Anglosphere. ${ }^{15}$ Such innovation, as international historians whose work has touched on intelligence matters have ably demonstrated, is now both possible and can be highly rewarding. ${ }^{16}$

In part, this article employs recently released records from the National Archives of India and the Nehru Memorial Museum and Library in New Deli to recover the significance of hitherto neglected local actors in the history of a covert Cold War conflict waged in India. New Delhi evidenced a concerned, if not always entirely productive response to political warfare operations conducted by foreign powers inside its borders. Disquiet over the damage that the dissemination of disinformation and, in particular, the publication of forged documents smearing national governments could do to New Delhi's relationships with international partners, ensured that India was never a passive player in the propaganda Cold War. Indian governments were acutely aware that covert disinformation activity conducted by third parties in the subcontinent complicated their efforts to retain invaluable economic assistance provided by the United States and, concurrently, pursue closer defence and security relations with the Soviet Union. Other scholars have documented the strain that global competition between Moscow and Washington, in fields as diverse as economics, grand strategy, and cultural diplomacy, placed on India's policy of non-alignment. ${ }^{17}$ The intelligence Cold War in South Asia acted as a further, concomitant source of stress on New Delhi's foreign policymaking, subverting India's attempts to retain the goodwill and support of the United States and the Soviet Union.

Back in early 1967, Chester Bowles had anticipated an upsurge in Communist propaganda in the subcontinent and, more specifically, an increase in Soviet disinformation designed to weaken American influence in India. Writing the previous November to the veteran US diplomat, Averell Harriman, he expressed the conviction that having recently suffered reverses elsewhere in Asia, and notably in Indonesia, following a military crackdown on the local communist party, the PKI, or Partai Komunis Indonesia, Moscow 'almost surely will give India the highest priority.' Moreover, Bowles reasoned that with the Sino-Soviet split widening, and India constituting 'the only massive political balance to China in Asia', it would become, 'essential for the USSR to establish an effective, responsive Communist Party here [India] as an ideological base from which to operate with the other underdeveloped nations. ${ }^{18}$ For an Ambassador known to harbour 'a visceral dislike of covert operations', the Soviet black propaganda offensive in India proved especially irksome. Before Bowles' posting to New Delhi, Desmond FitzGerald, who served as the CIA's Deputy Director of Plans, ensured that 
he was kept away from intelligence oversight while serving as Under Secretary of State for Political Affairs in the Kennedy administration. Extending Bowles authority over covert operations, Fitzgerald observed sardonically, would be akin to entrusting a ship to a captain who hated the sea. ${ }^{19}$

The open appeal that Bowles directed at Soviet intelligence agencies through the American Reporter to, 'Keep the Cold War Out of India', was almost absurdly antiquated. The Indian subcontinent had a long and controversial association with covert intelligence activity. Back in the eighteenth-century, the British East India Company had developed sophisticated networks of local spies and propagandists to consolidate and extend its influence in South Asia. ${ }^{20}$ In turn, British colonial rule in India was, in no small part, facilitated by what one scholar has characterised as a ubiquitous and highly efficient imperial system of political surveillance and military intelligence. ${ }^{21}$ Reflecting on his experience serving in India at the height of the British $R a j$, one military officer recorded that, 'there can never be any secrets in India, it is rather like living in an illuminated greenhouse.' 22 Indeed, the British Empire itself, of which India came to represent the jewel in the crown, constituted a veritable 'empire of intelligence', whose very survival hinged on a capacity to obtain and process information on the social and political lives of its subjects. ${ }^{23}$ British intelligence officers worked assiduously not only to suppress the forces of local nationalism, but also to forestall Russian imperial encroachment into India. Lionised on the pages of fictional works penned by London's preeminent imperial scribe, Rudyard Kipling, on the ground in the subcontinent, British and Russian officials secretly engaged in a 'Great Game' for territory, power and prestige. ${ }^{24}$ The rise of the Soviet Union after the October revolution of 1917 did little to dampen Russian interest in India, and the 'Great Game' continued largely unabated up to, and beyond, Britain's retreat from South Asia in August 1947.25

Indeed, following India's independence, New Delhi's policy of Cold War non-alignment facilitated the presence of sizable diplomatic and commercial missions in the country from both sides of the Iron Curtain. Moreover, the Cold War's shifting geography all but guaranteed that India would play an important part in an updated variant of the 'Great Game.' Directly to the north of India lay the Communist colossuses of the Soviet Union and the People's Republic of China. In 1955, an exchange of state visits between Indian's prime minister, Jawaharlal Nehru, and the Soviet premier, Nikita Khrushchev, invigorated moribund bilateral relations. Economic and technical assistance began flowing into India from the USSR, while politically Moscow courted Indian favour by using its veto in the UN Security Council to support New Delhi's claim on the disputed state of Kashmir.

Equally, in the latter half of the 1950s, during Dwight D. Eisenhower's second presidential term, Washington became alarmed by the expansion of Soviet influence in the subcontinent and the electoral success achieved by the Communist Party of India (CPI). By the end of the decade, CIA estimates placed the CPI's membership at some 258,000, making it the fourth largest Communist Party outside the Eastern bloc. ${ }^{26}$ Above all, in 1957, the decision taken by Indian voters to return a CPI government in Kerala, in southern India, sent shockwaves through America's political establishment. ${ }^{27}$ Efforts by Eisenhower's administration to strengthen Indo-US relations, principally through the provision of economic assistance, were subsequently extended by President John F. Kennedy. Kennedy came to see India as a crucial democratic counterweight to communist power in Asia. For the majority of Kennedy's truncated presidency and, most evidently, for a brief period following the Sino-Indian border war of 1962, Washington's effort to contain Asian communism was not focused on South Vietnam, but on South Asia. ${ }^{28}$

Inevitably, the importance attached to India by the Soviet Union and the United States ensured that foreign intelligence agencies were highly active in the subcontinent. ${ }^{29}$ The former British Secret Intelligence Service (SIS) officer, and Soviet spy, George Blake, recorded that 
India was valued in Western intelligence circles as it offered, 'the most favourable conditions...for establishing contacts with Soviet citizens. ${ }^{30}$ The presence in India of large numbers of diplomats, non-governmental organisations, technicians, businesspeople, and journalists from the USSR, UK, and the United States, offered considerable scope for the covert acquisition of information, the dissemination of black propaganda, and the recruitment of agents and defectors. It was in New Delhi, in the 1960s, that Stella Rimington, a future Director General of the British Security Service (MI5) was inducted into the secret world. Recruited as an assistant to the local MI5 representative, or Security Liaison Officer (SLO), Rimington discovered that, 'the battle for influence or control in India which had been waged between Russia and Britain since the $19^{\text {th }}$ century continued.' The subcontinent, Rimington marvelled, 'was overrun with foreign advisers, military advisers, agricultural advisers, industrial advisers, economic advisers and every other kind of adviser you can imagine. As we toured the country we kept falling over them. ${ }^{31}$

What applied to SIS and MI5, also held good for America's Central Intelligence Agency (CIA), and Eastern bloc intelligence bodies, including the Soviet Committee for State Security (KGB) and foreign military intelligence (GRU), and the overseas arms of East German and Czech intelligence. From 1947, the CIA began to establish a substantial operational presence in India. Beginning with a single 'station,' or office, in New Delhi, the Agency steadily extended the geographical scope of its activities, establishing a network of outposts in Bombay, Calcutta, and Madras. One American official assigned to New Delhi in the 1960s, confirmed that US intelligence involvement in India was, 'very large, and very invasive . . the CIA was deeply involved in the Indian Government." ${ }^{32}$ Before taking up his post as Kennedy's ambassador in India, a CIA briefing on covert operations left the Harvard economist, John Kenneth Galbraith, 'appalled and depressed'. Galbraith reasoned that Agency plans to channel millions of dollars to non-communist Indian politicians, subsidise pro-Western Indian journalists and newspapers, and violate Indian airspace in support of Tibetan dissidents resisting Chinese rule, were likely to be ineffective, subject to public exposure, and prove politically incendiary. Incensed by what decried as reckless 'adventurism', the Ambassador waged a campaign to shut down CIA operations. Galbraith's efforts to circumscribe Agency activity proved to be, at best, only partially successful. ${ }^{33}$

Concurrently, a succession of dynamic KGB chairman, such as Alexander Shelepin, Vladimir Semichastny, and the future Soviet leader, Yuri Andropov, zealously prosecuted Moscow's strategy of sponsoring wars of national liberation and undercutting Western influence across the global South. ${ }^{34}$ On Andropov's watch, Soviet intelligence agencies expended a sizable proportion of their resources, outside of Europe and North America, in India. ${ }^{35}$ Oleg Kalugin, then a rising star in the KGB's First Chief (Foreign Intelligence) Directorate, has documented that the Soviets 'had scores of sources throughout the Indian government - in intelligence, counterintelligence, the defense and foreign ministries, and the police. The entire country was seemingly for sale, and the KGB and the CIA had deeply penetrated the Indian government. ${ }^{36}$

British counter-subversion officers from MI5, who provided the Indian Intelligence Bureau (IB) with training and advice, became 'depressed' by the inability of their colleagues in the subcontinent to recognize and respond effectively to threats posed by an explosion in the Soviet intelligence presence. One disgruntled MI5 officer grumbled in the mid-1960s that, when it came to India, 'in effect they [the Soviets] are having an almost free run for their money both in the espionage and subversive fields.' ${ }^{37}$ Echoing the concerns expressed by British colleagues, the CIA warned American policymakers that the Soviets 'intensive propaganda' programmes in the subcontinent underscored that, 'India has [a] high priority in the Kremlin's program to destroy Western prestige in the underdeveloped countries. ${ }^{38}$ The deep and pervasive nature of external intelligence operations in India has been corroborated by members 
of New Delhi's own security and intelligence services. T. V. Rajeswar, a former director of India's Intelligence Bureau, has noted that the subcontinent was an especially 'happy hunting ground for intelligence agencies from all over the world. ${ }^{39}$

\section{Soviet Disinformation and Forgery in India}

Reflecting on his service as the first head of the CIA's Soviet division, and the Agency's station chief in New Delhi between 1957 and 1962, Harry Rositzke opined that, 'the most effective form of KGB disinformation work is the forgery and distribution of "genuine" documents from inside the U.S. Government to highlight its aggressive intentions and interventionist policies... these forgeries have had the greatest impact in the Third World, both on government elites and on public opinion. ${ }^{40}$ The belief that the Global South was especially vulnerable to Soviet disinformation operations was widely held inside the CIA. An Agency report from March 1960 observed that the 'effectiveness' of forgery campaigns depended largely on the geographic area targeted. 'In politically sophisticated areas such as Western Europe the forged "secret document" has been so heavily used by generations of secret police and political extremists...that any "disclosure of secret documents," true or false, is apt to be greeted with public scepticism,' Agency analysts concluded. 'In the underdeveloped areas, however, the level of political sophistication is low and the forgeries undoubtedly find some acceptance...' Brushing over broader geo-strategic drivers underpinning the expansion of Cold War propaganda activity beyond Europe, the increasing frequency with which Eastern bloc intelligence services had targeted 'the underdeveloped areas of the world', it was argued, validated such an thesis. ${ }^{41}$ The orientalist attitude to disinformation activity that permeated the CIA, in an Indian context, at least, was deeply flawed. Ample exposure to colonial propaganda, allied to a vibrant and adversarial political culture, as we shall see, led Indians and their nationalist leaders to approach black propaganda conducted through forgery with a healthy degree of scepticism and suspicion.

Less problematic, was Rositzke's identification of India as a major focus for Soviet disinformation activity. Forgeries purporting to be official State Department documents featured regularly in left-wing news magazines, such as Blitz and Link. Such 'fake news' was placed in India's mainstream media in 'a hundred ways.' Local KGB agents and compliant news editors, Soviet contacts in diplomatic, academic and government circles, and journalists and publications benefiting from covert financial subsidies, were all employed to surface forged texts. Once published in India, stories based on forgeries were picked up and replayed by other countries through regular press sources, carried in the Soviet print media via TASS and Izvestia, and broadcast over Radio Moscow. The process did not only benefit Eastern bloc propagandists. Many Indians with little, or no, ideological affinity for either side in the Cold War, proved more than willing to take advantage of Soviet and American largesse. In the late 1950s, when bemoaning an attempt to place articles in the Indian press, one East German official complained that the Delhi Times had agreed to publish unattributable material from behind the Iron Curtain, but only in return for generous financial compensation. ${ }^{42}$

Curiously, back in 1952, Chester Bowles had been one of the first to fall victim to a Communist forgery ploy in India. The year before, Bowles had been posted to New Delhi by Harry Truman to serve his first stint as US Ambassador. On 30 September, Current, a Mumbai news magazine, published a photostat of letter purported written by Bowles to Russi K. Karanjia, the editor of Blitz. In the letter, which Bowles decried as a 'bare-faced forgery', the Ambassador was quoted as expressing a willingness to meet secretly, and work with, Indian Communists. ${ }^{43}$ An irate Bowles successfully lobbied the Indian government to open an enquiry into the incident. Also unhappy at 'slanderous' attacks levelled at his government by Blitz, and other Communist publications, India's Prime Minister, Jawaharlal Nehru, accepted advice 
from his officials to, 'consider whether something should not be done to stop or counteract this type of malevolent press propaganda which we, Ministers and Secretaries alike, must all deplore. ${ }^{44}$ However, perhaps as its authors had intended, the US Ambassador's determination to get to the bottom of the forgery episode backfired. Citing the sanctity of journalist's sources, D. F. Karaka, the editor of Current, refused to reveal how he had come by the forged document. Karaka and Karanjia were arrested by Indian authorities on charges of forgery and wilful publication of forged documents. In a drama that the Indian press ensured received blanket coverage, the editors were acquitted by a Mumbai court, and then promptly rearrested by local police in a legal saga that dragged on for months. Ultimately, the origin of the forgery remained obscure. What became clearer, however, was that support Bowles and his Embassy had accrued in the Indian press immediately following the forgery's publication, turned to irritation and open hostility, as the United States' attempt to obtain legal redress became associated, fairly or not, with an assault on the freedom of the press in the subcontinent. ${ }^{45}$

Under Karanjia's direction, Blitz proved to be a considerable thorn in the side of Western governments. The British denounced the magazine as 'a scurrilous, sensational type of paper, edited by an unscrupulous Parsae [sic]... whose reputation is that of a fellow-traveller, if not a Communist. ${ }^{46}$ One former CIA officer confirmed that Blitz was regarded as a Sovietcontrolled, "tabloid "rag" of propaganda and disinformation... which had influence beyond India, and ... preoccupied us considerably. ${ }^{47}$ Specifically, Blitz was identified by the CIA as one of the most prominent vehicles for the replay of Soviet forgeries, alongside the East German newspaper, Neues Deutschland, and the Cairo daily, Al Ahram. Karanjia, although assiduous in eschewing association with local Communists, was personally marked out by the Agency as an, 'obvious... Soviet bloc...propaganda agent.' Labelled by the CIA as a 'silent partner', or controller of a news outlet acting as a vehicle for ultranationalist and pro-Soviet propaganda, Karanjia cultivated a wide circle of contacts in Indian politics, the media, and amongst foreign diplomats. These, the Agency concluded, were utilised by Karanjia, 'for the purposes of verbal promotion of rumour, picking up libellous gossip for replay to a member of his newspapers staff (posing as an informant on the owner), to local police and foreign intelligence agencies... 48

Over the course of just a few months in late 1957 and early 1958, Blitz carried no fewer than eight prominent stories centred on the exposure of purportedly genuine US government documents. In July 1957, a forged State Department directive was reproduced in which the US Ambassador to Thailand, Max Waldo Bishop, appeared to receive instructions to use local US intelligence facilities 'to screen the loyalty of the [Thai] King and his Government members.' On 21 September, two forged cables allegedly sent by the US Ambassador in Taiwan, Karl Rankin, were printed. In these, Rankin was seen to discuss methods of assassinating the Chinese nationalist leader, Chiang Kai-shek. The Rankin 'cables' were subsequently replayed over Radio Peking, in broadcasts beamed into Taiwan. A week later, Blitz featured copies of a further two forged cables from the US Ambassador to Jakarta, John Allison. On this occasion, the forgeries outlined American plans to aid rebels in overthrowing Indonesia's President Sukarno. Further stories based on forged US government documents followed in quick succession. Among these, Blitz detailed Washington's supposed support for post-Suez Israeli plans to annex Arab territory; the existence of a secret US-Japanese pact to deploy Japanese combat forces on the Asian mainland; an American intention to use SEATO to secure control of Asian nations armed forces; disclosures of Communist sympathies within the Nationalist Chinese military; and further moves by Eisenhower's administration to coopt Taiwan and the Philippines in subverting Indonesia's government. At times, Blitz appeared to coordinate the publication of forgeries with the Delhi Times, a newspaper dismissed by the CIA as another 'chronic purveyor of Bloc propaganda', and 'a second-rate imitation' of its Mumbai counterpart. The Delhi Times was heavily subsidised by Eastern European, or 'Bloc friendly', 
missions in India. These accounted for purchases of up to half the newspapers print run, amounting to between 3,000 and 5,000 copies. In turn, material showcased in the Indian newspaper frequently reappeared days, or weeks later, in the wider Asian Communist press, such as La Patrie [The Homeland], a weekly published in Bangkok, and in Djakarta, through Berita Mingu [Sunday News]. ${ }^{49}$

The CIA, along with colleagues in the British Information Research Department (IRD), a shadowy secret propaganda arm of the Foreign Office, with close links to SIS, followed Blitz's contribution to a 'progressive increase in [the Soviets] use of forgery as a propaganda weapon', with some apprehension. Although the Indian publications weekly circulation of around 30,000 copies remained relatively small, its focus was not on mass propaganda. Rather, as American intelligence officers underlined, Blitz's impact resided in providing, 'a rallying point in drawing together and guiding the propaganda of small, non-Communist, political, theological and pacifist organisations in the area [India]. ${ }^{50}$ Indeed, the 'noticeable increase' in Soviet black propaganda-by-forgery at the end of the 1950s, which saw 32 known cases recorded, and in which Blitz featured heavily in both surfacing and replaying counterfeit documents, led the CIA to launch an 'intensive investigation' into the scope, scale, and impact of such an unwelcome development. ${ }^{51}$ Marvelling at the surge in forgery output, wags in the CIA headquarters at Langley, Virginia, reasoned that such tireless work on the part of Soviet intelligence officers had undoubtedly resulted in the creation of 'some Heroes of Socialist Forgery.' More troublingly, CIA analysts identified a new trend which suggested that Soviet forgery activity had been honed into a propaganda tool capable of quickly and efficiently responding to shifts in East-West relations. In the months prior to the abortive Paris summit, scheduled to take place in May 1960, between the leaders of the US, USSR, Britain and France, a 'damping' in the number of Soviet forgeries occurred. Between the acrimonious collapse of the summit, and the American presidential election the following November, the appearance of Soviet forgeries increased sevenfold, and on a clockwork schedule of one new forgery per month. ${ }^{52}$

The uptick in Soviet disinformation prompted Richard Helms, then Assistant Director of the CIA, to testify before a Senate Subcommittee on the subject of 'Communist Forgeries.' Appearing on Capitol Hill in June 1961, Helms outlined a Communist propaganda menace to American interests that 'grows daily more intense'. Helms asserted that, 'the Russians have a long tradition in the art of forgery', that stretched back to the czarist intelligence service, and its work in concocting anti-Semitic fabrications, such as the Protocols of the Elders of Zion. More recently, the Assistant Director declared, Moscow had begun, 'to aim them [forgeries] frequently against American targets, to turn them out in volume and to exploit them through a wide-flung international network.' In the vanguard of Soviet efforts, 'to drive a wedge between the peoples of non-bloc countries and their governments' by employing 'a bible of libel', Helms noted, were "Charley McCarthys", or dummies parroting the words of others, typified by nominally free world newspapers, such as Blitz, that were "consistently used as an outlet for Communist propaganda.' Listing detailed examples of a string of forgeries published in Blitz, Helms emphasised the CIA's determination to continue publicly exposing communist fabrications. 'The more lies we skin and nail to the door for all the world to see, the more aware the audience will be that the bloc lies, how it lies, and why it lies,' Helms submitted. 'As the bloc's chief propagandist [Nikita Khrushchev] told us not so long ago, they expect to bury us - in forgeries, apparently. ${ }^{53}$

When gauging reactions to Helms' testimony, the CIA concluded that it had served a valuable purpose in exposing the Communist technique of forgery to a wider domestic and international audience, and would prove a useful point of reference for American diplomats when they had cause to broach the issue of Soviet disinformation with their host governments. With Helms' encouragement, Leonard Marks, Director of the USIA, produced a booklet 
designed for foreign distribution, that was based on the forgery material disclosed in the Senate Subcommittee hearings. ${ }^{54}$ The fact that Helms' intervention was not subject to greater counterattack in the global Communist press was interpreted as further evidence of its impact. The weight and detail contained within the cases of forgery outlined by its Assistant Director, the Agency reasoned, suggested communists judged that it would be 'distinctly unprofitable' to subject the testimony to open challenge. One of the only public ripostes came from Karanjia who, CIA officers reported with satisfaction, had confined criticism of Helms' attack on Blitz to the limp assertion that, '...the contents, if not the documents themselves [published by his newspaper], stood corroborated by exposures of CIA activities...

\section{India's Year of Intelligence}

As the 1960s progressed, the CIA's counter-offensive against Soviet black propaganda that had been launched by Helms was compromised by unwelcome ghosts from the Agency's past. Notably, in February 1967, Langley was aghast when the American west-coast magazine, Ramparts, revealed that the CIA had funded a global network of educational and cultural organisations. In exposés that were reprinted in The New York Times and The Washington Post, Ramparts laid bare the Agency's covert funding of bodies such as the National Students Association, Asia Foundation, and Congress for Cultural Freedom (CCF). In India, where a general election campaign was underway, a wave of popular rancour greeted the disclosure that the Indian Committee for Cultural Freedom, an offshoot of the CCF, had been bankrolled by the CIA. Chester Bowles noted presciently that repercussions from the Ramparts calamity would be keenly felt in in India, 'where we [the United States] had developed especially close and extensive relationships with Indian universities and with individual scholars, none of which were in any way connected with intelligence operations. ${ }^{56}$

Matters went from bad to worse the following month when, in an article carried by The Washington Post, John Kenneth Galbraith derided the CIA as, 'a secret agency . . . with an excellent instinct for headlines.' In publicly recounting his interactions with the Agency in the subcontinent, Galbraith claimed that CIA 'activities were generally known to, and involved no conflict with, local [Indian government] authorities. ${ }^{, 57}$ Infuriated by Galbraith's imprudence, Helms, by now the Agency's Director, fumed that the former Ambassador had succeeded in 'rais[ing] unshirted hell in India and [had] . . . provided the central point of an acrimonious debate in the Lok Sabha [India's parliament]. ${ }^{58}$ At the same time, a pamphlet appeared in India authored by John D. Smith, a former code clerk at the US Embassy in New Delhi, who had taken up residence in the Soviet Union. First serialized in Moscow's Literaturnaya Gazeta, Smith's scurrilous tract, I was a CIA Agent in India, detailed purported Agency machinations designed to subvert the Indian government. Smith's allegations included a claim that the CIA had sabotaged an Air India flight carrying Chinese diplomats to the Bandung conference in 1955. Derided as a ludicrous fabrication by Western officials, and subject to an IRD counterpropaganda campaign all of its own, Smith's book nevertheless amplified many Indians' misgivings surrounding US encroachment in the subcontinent's political affairs. ${ }^{59}$ In turn, sensing an opportunity to stoke public outrage and secure votes, India's politicians evidenced an increasingly anti-CIA posture. On March 23, India's Foreign Minister, M. C. Chagla, declared that a 'thorough' official investigation would be launched to determine the extent of CIA interference in India's domestic affairs. 'We cannot permit foreigners or foreign governments to dictate to us what sort of a government we should have or what sort of people should be elected,' Chagla announced. 'We will unearth any activity that is objectionable, that is against the national interests.' 60

Anxiety that an anti-CIA witch hunt in India would expose Britain's own covert propaganda operations, the British High Commissioner in New Delhi, John Freeman, suspended some local 
IRD activity. ${ }^{61}$ A journalist by trade, Freeman had been sent to India in 1965 by the Labour Prime Minister, Harold Wilson. He was quickly embroiled in a diplomatic spat with his host government, after Wilson angered Indians by appearing to blame New Delhi for escalating a conflict that had broken out with Pakistan in the autumn of that year. Freeman confided to the Labour cabinet minister, Tony Benn, that Moscow was actively working to exploit Indo-British discord, and aggressively pursuing a, 'Russian interest...to disengage the British from India. ${ }^{\text {'62 }}$ Back in London, IRD officials echoed Freeman's concern 'that [the] Russians are now stepping up disinformation activities.' Much of the Soviet covert propaganda output, the British rued, evidenced 'rather an I.R.D. character', and had taken to employing 'unconscious or semiconscious "agents of influence", encompassing both journalists and politicians, who worked within local laws and were frustratingly 'difficult to pin anything on.' 63

Freeman was mindful that a public unmasking of IRD's own illegal use of unattributable propaganda in India would spark a political storm. Worst still, disclosure of Britain's recourse to 'black' propaganda in the subcontinent, including the distribution of forged documents smearing communists, was likely to have major diplomatic repercussions. Back in May 1962, the British had been placed in an awkward position when MI5's SLO in New Delhi was approached by the Indian Intelligence Bureau regarding a suspicious document then circulating in the country, that purported to originate with the Secretariat of the Chinese People's Committee for World Peace, based in Beijing. The British SLO recognised the document immediately as an IRD forgery, on which he had been briefed back in London prior to his posting to India. In an effort to mask its true origin, the British MI5 officer was advised by the Security Service and IRD to 'deny all knowledge' of the forged document and, in a remarkable display of bravado, offer to examine the document for the IB and provide an expert, and disingenuous, 'expert opinion' on its veracity. ${ }^{64}$

In this context, the events of 1967 saw Freeman order IRD field officers not to recruit new Indian contacts; to avoid interaction with established 'assets'; and to exercise extreme caution in the payment of monetary 'incentives.' Freeman's decision to 'pause' IRD work was driven by the concern that the Indian scrutiny of the CIA might, "unearth the activities of other Western Missions and perhaps link these with the C.I.A. Here we [the British] should be an obvious target.' Moreover, an Indian shift to the left, that saw Communist-led state governments installed in Kerala and West Bengal, raised British concerns that, 'the spread of communist influence is now likely to enter the field of Indian domestic politics, and...in the process, the ability of the State Governments to uncover - or fabricate - 'foreign influences' is of course increased. ${ }^{65}$ Worryingly for the British, the heightened Indian interest shown in the CIA did translate into questions on the organisation and role played by the United Kingdom's foreign intelligence services. At diplomatic reception held just after the Ramparts story broke, Freeman was startled when, Triloki Nath Kaul, India's Secretary at the Ministry of External Affairs, directed 'a sharp question' in his direction, asking the High Commissioner pointedly, "What is the British equivalent of the C.I.A.?". The same question was repeated by a second Indian at a lunch hosted by Britain's Information Counsellor a few days later. 'We do not want to read too much into Kaul's behaviour,' the British High Commission advised London, 'but it certainly shows the way in which his mind, for whatever practical objectives, tends to work. ${ }^{66}$ Freeman's apprehension that intelligence scandals spelt trouble for Western interests in India, were well founded. What the British High Commissioner failed to anticipate, however, was that he would be personally placed at the centre of a Soviet disinformation ploy.

\section{The Freeman Telegram}

On 9 February 1967, as the Ramparts revelations were about to be aired in America's press, John Freeman sent an urgent cable from New Delhi to Whitehall. Freeman reported that a 
friendly local journalist, Frank Moraes, from the Indian Express, had passed the British High Commission a photostat copy of a purportedly secret telegram. The telegram in question, which was addressed from Freeman to London, named members of the US Embassy staff in Delhi, and suggested that they were involved in passing covert payments to pro-American Indian parliamentarians and right-wing political party's campaigning against the ruling Congress government in national elections. 'Although there are sufficient fallacies to convince any sophisticated reader of its real nature,' Freeman noted, 'it [the telegram] could certainly confuse and probably deceive those who are uninitiated in our professional ways.' Alarmed that the cable would be cited by an India media highly sensitized to allegations of American interference in the nation's domestic affairs, and subsequently replayed by Soviet propagandists, Freeman rushed to forewarn American colleagues, and officials at India's Ministry of External Affairs (MEA), that a forged document was circulating within the pressrooms of Indian newspapers. ${ }^{67}$ Anticipating the telegrams appearance in Blitz, Freeman agreed with American counterparts that, on its publication, they would issue a common statement confirming, 'that the telegram is a blatant and crude forgery, and that we have been in touch with the Indian Government about it. ${ }^{68}$

The British inclination was to let the matter rest there, and 'to treat the whole incident lightly... and to take the line, when questioned, that the forgery is too clumsy to be taken at all seriously. ${ }^{69}$ The US Embassy elected to take a more combative approach. A draft statement prepared by America officials attacked the forgery as, 'a contemptible and unskillful attempt to blacken the name of the U.S. and to influence the course of the Indian elections. ${ }^{70}$ Attempting to seize the initiative, and blunt the impact of the telegrams publication, Bowles, accompanied by Leonard Weiss, his Minister Counsellor, called on Lakshmi Kant Jha, head of the Indian Prime Ministers secretariat, and an individual not unsympathetic to the United States. Making clear in the strongest terms that Washington was losing patience with the appearance of forgeries maligning the United States, Bowles advised Jha that he was in possession of information that pointed to Soviet involvement in a disinformation campaign being mounted in India. Furthermore, the American Ambassador named Yuri Modin, recently arrived as Consul at Soviet Embassy in New Delhi, and known as intelligence officer, as behind the latest forgeries. Intriguingly, in the 1950s, Modin had served as Soviet controller of the 'Cambridge Five' spy ring, whose British members included Kim Philby, Donald Maclean, Guy Burgess, Anthony Blunt and John Cairncross. Confirming that his Embassy intended to 'make a public row if this sort of thing continued', Bowles pointedly asked Jha how an unsavory diplomatic squabble between the United States and Soviet Union, centered on India, might best be avoided? Anxious that India was not drawn into a dispute between the two superpowers, Jha arranged for American officials to meet for talks with colleagues in the Ministries of External and Home Affairs. ${ }^{71}$

Weiss wasted no time in calling at the MEA to raise the matter directly with K.S. Bajpai, Director of its American Section. Bajpai's notes of the encounter record Weiss's 'irritation and concern' at the scale of forgeries published in the Indian press, and their intention to poison Washington's relations with New Delhi. Assuring Bajpai that he was 'convinced beyond all doubts that the Soviet Union was behind the distribution of these forgeries', Weiss reiterated that, 'if this practice were continued there would be a first-class row as the Americans would have to issue statements and there might be a running exchange between them and the Russians.' Weiss's intervention had little impact inside the MEA which, accurately or not, was generally perceived by Western embassies as difficult to deal with, if not overtly pro-Soviet. Although acknowledging 'the evident working up of emotions among the Missions accused of wrong doing', Bajpai asked what, precisely, the US Embassy expected his government to do? In the absence of incontrovertible evidence of Soviet involvement, Bajpai made clear to Weiss that, 'obviously we [the MEA] could not send for the Russians and say the Americans had told 
us that the USSR was conducting this campaign.' Equally, a disgruntled Weiss was informed that, given the operation of a free press in India, 'if there were politically committed papers wanting to discredit Western countries, there was little we [the Indian government] could do to stop them.' Unsatisfied, Weiss pressed Bajpai to intervene, and to order Blitz not to publish the Freeman telegram. In response the Indian official observed that his American colleague, 'would surely appreciate the unlikelihood of Mr. Karanjia taking any advice from the Government of India.' To Bajpai's surprise, a piqued Weiss ended their encounter by stating that he was seeing India's Home Secretary later that day, and would revisit the issue of the Freeman telegram at a more senior level of the Indian government. ${ }^{72}$

The American conviction that the Freeman telegram was the work of Soviet intelligence was not shared by British colleagues. The IRD concluded that the forger was more likely to be an Indian Communist than an Eastern Bloc propagandist. In large part, the British position was informed by the poor quality of the forgery. Officials in the British High Commission recorded that IRD officers were, 'reluctant to believe that a Soviet Intelligence Officer could have been so clumsy. ${ }^{73}$ Although the British reasoned that the forgery 'was obviously made by someone in possession of a duplicated telegram of some kind in the Foreign Office/Whitehall distribution', it did contain a number of mistakes. Freeman was named as 'Sir John Freeman' in the cable. The High Commissioner had not been ennobled. The telegram was also addressed from 'Delhi' to the 'Foreign Office', when an official British communication from India would have been addressed from 'New Delhi' to the 'Commonwealth Office'. In addition, to the horror of Whitehall, the telegram was full of errors of grammar, and written in a "noticeably "un-English"' style. ${ }^{74}$ Joe Garner, Permanent Under-Secretary of State at the Commonwealth Office, found the Freeman forgery to be 'fascinating', but did wonder why Communist forgers 'imagine that we [British diplomats] still write in the style of Gibbon?'75

As the British and Americans had suspected, the Freeman telegram did feature in Blitz, but not in the form anticipated. On 18 February, the Indian newspaper published a report by A. Raghavan, its Delhi correspondent, alleging that a 'British source' had confirmed the High Commission were concerned about covert American financing of right-wing Indian politicians and political parties, and Washington's interference in India's elections. The Freeman telegram itself, however, was not directly cited or reproduced. ${ }^{76}$ The British judged that the strength of the American reaction communicated to the Indian government had filtered through to Blitz, and led its editor to take a more circumspect approach than normal to the publication of a forgery. In addition, American officials determined that the forgers had made a fundamental mistake in naming specific Indians in the telegram, and opening up the prospect of litigation against newspapers that reproduced the full text. 'It seems probable that whoever prepared it [the Freeman telegram] failed to understand the Rule of Law as it is applied in India,' Bowles' staff suspected, 'particularly the law of libel and slander. For it is one thing falsely to say that the American Embassy has paid rupees to "anti-socialist candidates" and quite another to say that the recipients with C.B. Gupta, Minoo Masani and Atulya Ghosh [Indian Members of Parliament]. ${ }^{77}$

Having consulted with American colleagues, British officials persuaded the US Embassy to change tack, and temper reactions to the Blitz article and, if deemed necessary, to issue separate protests to avoid Communist charges of Western collusion in covering up an embarrassing revelation. Eager to avoid placing themselves in the Indian media spotlight any more than was necessary until after national elections had concluded, the British and American missions also aimed to deny Blitz the oxygen of publicity. 'A public denial,' British officials judged, 'would merely widen the article's readership.' Relieved that the mainstream India press had declined to reproduce or comment on the Blitz allegation, the British did note that Raghavan's report was replayed over Radio Moscow. 'In [the] eyes of Americans here this confirms Soviet involvement in the forgery,' a still skeptical Freeman informed London. '[The] United States 
Embassy are therefore more concerned to nail the Russians than Blitz, and will be making recommendations to State Department in this broader context. ${ }^{78}$

The more circumspect British approach to the forgery was underlined when Freeman met with Chandra Shekhar Jha, India's Foreign Secretary, towards the end of the month. Both men skirted around the forgery issue, declining to speculate on its precise origin. The British record of the encounter confirmed that, 'though the Soviet Embassy was evidently in the minds of both, it was not mentioned by name.' In contrast, the High Commission became aware that Bowles and his Embassy had reconsidered their position, and had gone back on to the offensive. 'The Americans make no bones of the fact that they have not been so reticent,' one of Freeman's staff reflected, 'and in talks with Indian Government officials have openly accused the Russians of being responsible for this forgery and other malicious anti-American propaganda. ${ }^{79}$ Galen Stone, Counselor at the US Embassy, kept pressure on the Indian government by paying regular visits to Bajpai at the MEA, and leaving the Indian official with lengthy and detailed reports of what the Americans categorized as, 'a major campaign in India based on forgeries, the mailing of unattributable propaganda, and the printing of wholly baseless articles in the press.' The, 'bald faced effort to create discord between India and the United States', Stone emphasised, seemed to have negatively affected the opinions of 'a number of influential Indians'. 'If it is permitted to go unchecked and unchallenged,' Bajpai was warned, 'the damage [to Indo-US relations] will become serious. ${ }^{\text {, }} 0$

The long litany of Communist forgeries passed on to Bajpai from the US Embassy included a disinformation campaign centred on a purported American plot to balkanize the east of the country, and create a 'United States of Bengal', by carving out territory from India and Pakistan. Another Communist back propaganda scheme, labelled 'Project Brahmaputra', focused on an alleged scheme to secretly promote US influence in eastern India. Forged documents claiming to establish the veracity of each, Bajpai was reminded, had surfaced in India Communist newspapers, including Patriot, Link and Mainstream, before being taken up in the Soviet press by Pravda. During 1967, however, the 'major effort' to blight Washington relationship with New Delhi, and influence the outcome of India's general election, US reports underscored, had remained the 'superficially plausible' Freeman telegram. Ominously, Bajpai was left in no doubt by senior American diplomats that, 'Unless the Indian authorities move promptly and effectively to trace and suppress this extensive clandestine propaganda apparatus, one may anticipate a continuation of this type of activity with a resultant adverse effect upon relations between India and the United States. ${ }^{81}$

\section{'Did the KGB Forge the Freeman Telegram?'}

Throughout the remainder of 1967, and beyond, Bowles' Embassy maintained pressure on the Indian government to adopt a more robust response to instances of disinformation-by-forgery. In May, as part of a public offensive that the American ambassador had initiated himself, with the publication of his article in the American Reporter, Tony Lukas, the New York Times' correspondent in the Indian capital, was encouraged to approach the British with a view to running a story on the Freeman telegram. By way of introduction, John Shirley, the US Embassy press attaché, briefed British officials that Bowles was eager to assist the Western press in exposing, 'the numerous anti-American activities at present rife in India.' The British, whose relations with New Delhi had yet to recover from the nadir occasioned by Harold Wilson's ill-judged intervention in the Indo-Pakistan war two years earlier, remained less keen to ruffle Indian feathers by making a fuss over the Freeman affair. Over 'a very long conversation' with Lukas, British officials stressed that they 'had no particular wish for extensive publicity about this matter', and declined to show the American reporter a copy of the Freeman forgery. Disturbed that, in briefing Lukas, the US Embassy had 'injudiciously' 
provided the New York Times' correspondent with a copy of the Blitz report on the Freeman cable, and speculated on the Soviet provenance of the forgery, the British stonewalled his questions. Asked directly by Lukas if the High Commission concurred with Bowles' position that, 'these forgeries and the type of propaganda they peddled were likely to increase in the future... [and] that the Russians specifically wanted to "carry the cold war into India"', the British responded with an icy, "no comment. ${ }^{82}$ Uncomfortably for the British, in a report published in the New York Times on 6 May, Lukas highlighted the Freeman forgery, referenced his contact with the High Commission, and underscored Bowles' concern that the United States respond vigorously to a, 'well organised [Communist] campaign to blacken the United States' reputation here [India]. ${ }^{83}$

Meanwhile, Galen Stone continued to furnish the MEA with American reports of Soviet disinformation activity in India. One report sent to Bajpai listed a further series of instances where Radio Moscow, and its sister station, Radio Peace and Progress, had directed broadcasts at India which repeated 'slanderous untruths' about specific American Embassy personnel, Peace Corps volunteers, and Indian public figures known to be friendly to the West. On 8 June, Radio Moscow lambasted the United States and the United Kingdom as, 'the enemies of the Indian people, that is, those overseas powers which would like to see India made a colony once again.' A sharp increase in the volume of Soviet disinformation reaching India led to questions being raised in the Indian parliament. On 8 August, India's Deputy Minister of External Affairs took the unusual step of publicly criticising incidents of 'very critical' broadcasts emanating from the Soviet Union. ${ }^{84}$

In December, the Indian government found itself further enmeshed in the forgery melodrama. During a debate on the activities of foreign espionage agencies held in the upper house of India's parliament, the Rajya Sabha, S. S. Bhandari, an MP from the Jana Sangh, a right-wing political party, responded to charges of CIA subversion levelled by CPI colleagues by raising the spectre of Soviet disinformation, and quoting extensively from the Freeman telegram. With the Freeman cable now the subject of Indian political discourse, the British High Commission felt compelled to issue a formal note decrying the telegram as a forgery. The British démenti was splashed over the front pages of India's newspapers the next day. When questioned on the telegram in parliament, India's Home Minister, Yashwantrao Balwantrao Chavan, confirmed that it was an obvious fabrication, and stated that he, 'would not hesitate to prosecute the persons responsible for the forgery.' The British welcomed Chavan's intervention as 'very satisfactory'. It had been informed by material that Freeman's officials had supplied to the MEA for just such a purpose. 'We have always found the Home Minister [Chavan] helpful in our dealings with him,' the British crowed. 'It is encouraging that he went out of his way to kill this story, and we should be surprised if any attempt were now made to revive it. ${ }^{85}$

At the same time, Bowles looked to sustain an Indian focus on Soviet disinformation, and deflect local media attention away from the CIA. Reentering the public debate on Cold War propaganda, the US Ambassador published a second excoriating attack on Moscow's conduct in the American Reporter. On 18 December, Bowles addressed an open letter to the editor of Radio Peace and Progress, in which he lambasted 'hostile' broadcasts slandering himself, American officials working in India, and the US government more broadly. 'According to your broadcasts,' Bowles reminded the Soviet editor, 'virtually every American now living in India is a secret agent working to block India's economic progress, to create internal strife and to bribe public officials.' Reiterating the appeal that he had issued several months earlier, to 'Keep the Cold War out of India', Bowles urged the Kremlin forgo 'bitter attacks' and work with the United States in promoting Indian development. 'If we slip back into the old cold war atmosphere,', the Ambassador counselled, 'we shall all be the losers - Russians, Americans, and Indians - and a historic opportunity will have been lost. ${ }^{, 86}$ 
Bowles intervention was aimed, as he characterised it to Arthur Goldberg, US Ambassador to the United Nations, 'to knock down the flood of anti-U.S. propaganda the Soviets are pouring into India. ${ }^{87}$ It had limited impact. Supportive of Bowles efforts to avert a disinformation war in the subcontinent, Goldberg nevertheless painted a pessimistic picture of a troubling disinclination on the part of Moscow and New Delhi work constructively with the United States on the global stage. In writing to thank Bowles for forwarding him a copy of his latest American Reporter piece, Goldberg observed:

I can quite understand your concern over the problem of Soviet planted anti-U.S. propaganda in India for the Indian delegation here at the UN, with the apparent encouragement of the Soviets, has frequently been unhelpful on issues where one might have expected them to be cooperative or at least neutral. I cannot agree more with your determination that we cannot afford a return to the cold war atmosphere and must attempt to work together. ${ }^{88}$

The frustrations shared by Bowles and Goldberg overplayed the efficacy of Soviet disinformation in India, and underrepresented the Indian government's aversion to it. One contemporaneous political report sent to New Delhi from the Indian Embassy in Moscow revealed the existence of, 'quite a lot of resentment in India of critical references of the broadcasts of the Radio Peace and Progress... in which some distinguished Indian leaders were maligned.' Indian officials in the Soviet capital had made clear to their Russian counterparts that, 'such partisan articles by Soviet publicity media were bound to affect relations between the two countries.' Although Moscow disclaimed any responsibility for Radio Peace and Progress, Indian protests did produce, 'a perceptible decrease in the volume of anti-Indian comments in... broadcasts. ${ }^{89}$ The Soviet decision to recalibrate its black propaganda, and aver largely counterproductive attacks on Indian nationals, provided little comfort for Bowles. The flow of Soviet disinformation into India that targeted the United States, continued unabated.

With American calls for a propaganda truce with the Soviets in India falling on deaf ears, US officials resumed their struggle to blunt Communist disinformation. In January 1968, the British High Commission noted with interest the appearance of an article in the popular magazine, Young India. The publications editor, Sagar Ahluwalia, British diplomats reflected, 'relies heavily on the Americans, from whom the article doubtless stems." 90 Financial incentives from American sources had undoubtedly encouraged Ahluwalia to carry earlier stories 'exposing' KGB funding of left-wing Indian parliamentarians. On this occasion, the article in question, provocatively entitled, 'Did KGB Man Forge the Freeman Telegram', rehearsed Bowles' conviction that Yuri Modin was the individual behind the forged British document. Modin had left India in April 1967, only nine months after his posting to New Delhi. This abnormally short tour for a Soviet 'diplomat', Young India asserted, represented 'proof, if any were needed, that Modin came to India only to interfere with the [national] elections.' Citing a Western 'source', the article went on to claim that Modin's credentials as a forger were firmly established, and that India's Home Ministry was, 'well aware of Modin's role in this sinister business.' The Indian government had been furnished with evidence from its Intelligence Bureau, Ahluwalia professed, 'that Modin...was the probable source of forgeries linking the United States Embassy, the Central Intelligence Agency, and the British ... High Commission to the Congress Party and to more conservative parties.' Demanding that Chavan name Modin as the forger, and take appropriate punitive action against the Soviet Embassy, the article called on its readers to, "join "Young India" in condemning this sort of K.G.B. propaganda, and in urging our Government to protest to the Soviet Union not to send any more K.G.B spies to New Delhi.' 91

The application of American pressure on the Indian government through 'friends' in the local press was amplified by official protests from Washington. Exasperated by the persistence 
of Soviet black propaganda in India, in March, Dean Rusk, the US Secretary of State, authorized Bowles to issue a formal statement protesting at a, 'series of forgeries surfaced by some who would seek to disrupt friendly relations between the United States and India.' Prominently referencing the Freeman telegram, Bowles statement, which was shown to the Indian government twenty-four hours prior to its public release, emphasized that Washington, 'have hoped, and continue to hope that India will cease being used as a disinformation cockpit by those who would disturb Indo-US relations. ${ }^{92}$ Bowles' latest appeal to moderate the escalation in superpower propaganda in the subcontinent, proved to be as fruitless as his first, that had been made almost exactly a year before. The United States' relationship with India would remain a focal point of Soviet disinformation activity until the very end of the Cold War.

\section{Disinformation Undiminished}

In November 1989, as in Europe the Berlin Wall fell, and the Cold War's endgame began to play out, the Hindustan Times, a leading Indian daily, published allegations that the CIA had been conspiring with opposition parties to subvert the government of Rajiv Gandhi, and his ruling Congress Party. Coming on the eve of a general election in India, in which the leftleaning Gandhi was expected to face a tough fight to secure a further term in office, the progovernment Hindustan Times claimed that a one-million-dollar grant had been funneled to the prime minister's political rivals by the CIA. Accompanied by photostats of purportedly official documents originating from the US Embassy in India, the State Department, and the CIA, the news report was dismissed by American officials as 'mischievous', based upon 'patent forgery', and 'designed to damage Indian-American relations at a critical time.' 93 Senator Daniel Patrick Moynihan, the New York Democrat, and former US Ambassador to India, attacked the Indian newspaper revelations as baseless, and informed by, 'a painful - dare I say, pathetic - forgery.' ${ }^{94}$ When it came to Soviet disinformation in India, little had changed, it seemed, since 1967.

Indeed, in the wake of the Freeman telegram controversy, although the Indian government did seek to restrict foreign interference in the nations domestic affairs, the United States in general, and the CIA in particular, remained prime targets for Communist disinformation activity in the subcontinent. In December 1971, India's premier, and Rajiv Gandhi's mother, Indira Gandhi, was infuriated by the Nixon administration's decision to "tilt" to Pakistan following the outbreak of Indo-Pakistani hostilities. After 1971, India's relationship with the United States was bedevilled by an atmosphere of mutual suspicion and mistrust. Bilateral ties were strained by tensions over issues as diverse as the war in South Vietnam; debts India had accumulated purchasing American foodstuffs; New Delhi's pursuit of nuclear weapons; and Gandhi's willingness to court Moscow's support. In this context, India provided fertile political soil in which Soviet black propaganda continued to flourish. Expressing a viewpoint widely held in British and American diplomatic circles, one senior official in Britain's IRD observed with weary resignation that, 'There is no end to Mrs Gandhi's gullibility or disposition to believe ill of the Americans, and I doubt there is much that can be done about this.' 95

In March 1976, the Indian parliament passed legislation regulating foreign contributions to political organizations, and limiting the type and scale of payments to Indian newspaper owners and intermediaries from third parties. Moreover, Indian parliamentary enquires undertaken at the time referenced covert Soviet interference in the country's domestic political affairs. On the whole, however, Soviet intelligence agencies, and their activities in the subcontinent, came in for far less attention than their American counterparts. In the mid-1970s, one British official observed that a lengthy Indian government note on, 'foreign money in India,' referenced the KGB less than half-a-dozen times. In the same report, the CIA was listed on 60 separate occasions. Equally, the British underlined that, 'qualitatively, the [Indian] note gives the 
impression that American interference is taken more seriously at the official or political level than Soviet interference.' 96

Back in the United States, State Department assessments of Soviet 'active measures', or aktivnyye meropriyatiya, including disinformation-by-forgery, highlighted a tendency on the part of countries inside the developing world to 'ignore or downplay' Soviet back propaganda. In October 1981, during a press conference covering Soviet disinformation and political operations, State Department officials singled out India for special mention. Moscow, American journalists were informed, continued to privilege Blitz as a vehicle, 'to publish forgeries, falsely accuse Americans of being CIA personnel or agents, and disseminate Sovietinspired documents.' Worryingly for the State Department, the Soviets appeared to have learned from experience and, over time, to have become more accomplished and efficient forgers. 'On the basis of the historical record,' American officials predicted, 'there is every reason to believe that the Soviet leadership will continue to make heavy investments of money and manpower in meddlesome and disruptive operations around the world.' In the case of India, at least, such warnings had proved to be well founded. ${ }^{97}$ As one British official had earlier noted, the Indian subcontinent constituted something of an experimental laboratory in which Soviet covert propaganda techniques were trialled and honed before being deployed across the developing world. 'The Russians have, of course,' and IRD officer mused, 'used their experiences in India in many ways as a model for penetration of other countries and indeed their connexions with India as a direct instrument. ${ }^{98}$

And what of the individuals, the personal victims of disinformation-by-forgery? In the case, John Freeman, after leaving India in 1968 and, following a brief stint as Britain's Ambassador in Washington, he withdrew from political life, and turned his hand to broadcast journalism. Encountering Freeman in London, shortly after his return from the subcontinent, Richard Crossman, the Labour cabinet minister, observed that he had become almost unrecognisable. 'John used to be a rather willowy, elegant young man with wonderful wavy hair,' Crossman confided to his diary, 'but he's thickened out and his actual complexion has roughened so that he looks like an extremely tough colonel of a polo-playing regiment just back from India - big and bluff.' 99 First hand exposure to Soviet disinformation operations, it seemed, obliged diplomats, as well as the nations that they served, to cultivate thick skins.

\section{Notes}

\footnotetext{
${ }^{1}$ Chester Bowles, 'Ambassador's Report: Keep the Cold War out of India', American Reporter, 26 Apr. 1967.

${ }^{2}$ See, for example, Paul Lashmar and James Oliver, Britain's Secret Propaganda War: The Foreign Office and the Cold War, 1948-1977 (Stroud: Sutton Publishing, 1998); Stephen Dorril, MI6: Fifty Years of Special Operations (London: Fourth Estate, 2000); Christopher Andrew, The Defence of the Realm: The Authorized History of MI5 (London: Allen Lane, 2009); and Rhodri Jeffreys-Jones, Cloak and Dollar: A History of American Secret Intelligence (New Haven: Yale University Press, 2003).

${ }^{3}$ Alma Fryxell, 'Psywar By Forgery', Studies in Intelligence, (5), (Winter 1961), 25-51, DOC_0000608985, CIA FOIA Online Reading Room (CIA FOIA).

${ }^{4}$ See, for example, Rory Cormac. Disrupt and Deny: Spies, Special Forces, and the Secret Pursuit of British Foreign Policy (Oxford: Oxford University Press, 2018). For a notable exception, see Eric D. Pullin, "'Money Does Not Make Any Difference to the Opinions That We Hold": India, the CIA, and the Congress for Cultural Freedom, 1951-58', Intelligence and National Security (26, 2-3), (April-June 2011), 377-398.

${ }^{5}$ See, Masha Kirasirova, 'My Enemy's Enemy: Consequences of the CIA Operation against Abulqasim Lahuti, 1953-54', Iranian Studies, (50, 3), (2017), 439-465.

6 'United States-United Kingdom Information Working Group Meetings: United Kingdom Brief', Jun. 1960, [Kew, United Kingdom National Archives, Public Record Office], FCO [Foreign and Commonwealth Office Records] 168/19.

7 'Clandestine Subversive Activities by Sino-Soviet Bloc Representatives in Public Information Media', Dec. 1958, CIA-RDP78-00915R001000360002-9, CIA FOIA.
} 
${ }^{8}$ For instance, Victor Cherkashin, Spy Handler: Memoir of a KGB Officer - The True Story of the Man Who Recruited Robert Hanssen and Aldrich Ames (London: Basic Books, 2005); Bob Woodward, Veil: The Secret Wars of CIA 1981-1987 (New York: Simon and Schuster, 1987), and George Crile, Charlie Wilson's War: The Extraordinary Story of the Covert Operation that Changed the History of our Times (New York: Atlantic Books, 2002).

${ }^{9}$ Recent scholarship has examined facets of the secret intelligence dimension of South Asia's Cold War including aspects of its propaganda component. See, for, example: Pullin, 'Money Does Not Make Any Difference'; and Paul M. McGarr, "'Quiet Americans in India": The Central Intelligence Agency and the Politics of Intelligence in Cold War South Asia.' Diplomatic History, (38, 5), (2014), 1046-1082; and 'The Information Research Department, British Covert Propaganda, and the Sino-Indian War of 1962: Combating Communism and Courting Failure?', The International History Review, (41, 1), (2019), 130-156.

${ }^{10}$ See, for example, V. Zubok, 'Cold War Strategies/Power and Culture: Sources of Soviet Conduct Reconsidered' in Richard Immerman and P. Goedde (eds.), The Oxford Handbook of the Cold War (Oxford: Oxford University Press, 2013), 305-22; Ladislav Bittman, The Deception Game: Czechoslovak Intelligence in Soviet Political Warfare, (New York: Balantine Books, 1972), 94; and Cormac, Disrupt and Deny, 143.

${ }^{11}$ Fryxell, 'Psywar By Forgery'.

${ }^{12}$ British Cold War covert activity has been addressed in, for example, Richard. J. Aldrich, The Hidden Hand: Britain, America and Cold War Secret Intelligence (New York: Overlook Press, 2002); Andrew Defty, Britain, America and Anti-Communist Propaganda, 1945-1953 (Abingdon: Routledge, 2004); and Chikara Hashimoto, The Twilight of the British Empire: British Intelligence and Counter-Subversion in the Middle East, 1948-1963 (Edinburgh: Edinburgh University Press, 2017). Official histories of British intelligence authored by the late Keith Jeffrey and Christopher Andrew have cast some light on the post-war operations of SIS and MI5. The formers narrative, however, drawing on privileged access to archives that remain off-limits to other researchers, comes to an end in 1949. See, Jeffrey Keith, MI6: The History of the Secret Intelligence Service (London: Bloomsbury, 2010), and Christopher Andrew, Defence of the Realm: The Official History of the Security Service (London: Allen Lane, 2009).

${ }^{13}$ See, for instance, Victor Marchetti and John D. Marks, The CIA and the Cult of Intelligence (London: Alfred Knopf, 1974); John Ranelagh, The Agency: The Rise and Decline of the CIA (London: Simon \& Schuster, 1986); Rhodri Jeffreys-Jones, The CIA and American Democracy (New Haven: Yale University Press, 1998); John Prados, Safe for Democracy: The Secret Wars of the CIA (Chicago, IL: Ivan R. Dee, 2006); and Tim Weiner, Legacy of Ashes: The History of the CIA (New York: Doubleday, 2007).

${ }^{14}$ Current understanding of Soviet Cold War intelligence operations mounted in the Indian subcontinent has largely been informed by the published works of former KGB and GRU officers. See, for example, Christopher Andrew and Vasili Mitrokhin, The Mitrokhin Archive II: The KGB and the Wider World (London: Allen Lane, 2005); Oleg Kalugin, Spymaster: My Thirty-Two Years in Intelligence and Espionage against the West (London: Smith Gryphon, 1994); Leonid Shebarshin, Ruka Moskvy (Moscow: Terra, 1996).

${ }^{15}$ Some notable and pathbreaking work had been undertaken in this area. See, for example, Philip Davies and Kristian Gustafson, Intelligence Elsewhere: Spies and Espionage Outside the Anglosphere (Washington, D.C.: Georgetown University Press, 2013).

${ }^{16}$ A notable recent example is, Dina Rezk, The Arab World and Western Intelligence: Analysing the Middle East, 1956-1981 (Edinburgh: Edinburgh University Press, 2017).

${ }^{17}$ See, for example, Dennis Merrill, Bread and the Ballot: The United States and India's Economic Development (Chapel Hill, NC: University of North Carolina Press, 1990); Andrew Rotter, Comrades at Odds: The United States and India, 1947-1964 (Ithaca, NY: Cornell University Press, 2000); David C. Engerman. The Price of Aid: The Economic Cold War in India (Cambridge, Mass.: Harvard University Press, 2018); and, Rudra Chaudhuri, Forged in Crisis: India and the United States Since 1947 (London: Hurst, 2014).

${ }^{18}$ Bowles to Harriman, 30 Nov. 1966, Box 438, Folder, Bowles, Chester 1, Averell Harriman Papers, Manuscript Division, Library of Congress, Washington DC [LOCMD].

${ }^{19}$ Thomas Powers, The Man Who Kept the Secrets: Richard Helms and the CIA (New York: Simon \& Schuster, 1979), 105 and 169.

${ }^{20}$ See, C. A. Bayly, Empire and Information: Intelligence Gathering and Social Communication in India, 17801870 (Cambridge: Cambridge University Press, 1996).

${ }^{21}$ Richard J. Popplewell, Intelligence and Imperial Defence (London; Routledge, 1995), 365. See also, Popplewell, 'The Surveillance of Indian Revolutionaries in Great Britain and the Continent, 1905-14', Intelligence and National Security, (3, 1), (1988), 56-76; and, Patrick French, Liberty or Death: India's Journey to Independence and Division (London: HarperCollins, 1997).

${ }^{22}$ Sir Adrian Carton de Wiart, Happy Odyssey: The Memoirs of Lieutenant-General Sir Adrian Carton de Wiart (London: Jonathan Cape, 1950), 131.

${ }^{23}$ See, Martin Thomas, Empires of Intelligence (Berkley, CA.: University of California Press, 2008).

${ }^{24}$ Peter Hopkirk, The Great Game: On Secret Service in High Asia (London: John Murray, 2006), 5. 
${ }^{25}$ Richard J. Aldrich and Rory Cormac, The Black Door: Spies, Secret Intelligence and British Prime Ministers (London: William Collins, 2016), 37; See also, Peter Hopkirk, Setting the East Ablaze: Lenin's Dream of an Empire in Asia (London: John Murray, 1984).

${ }^{26}$ Soviet Program in India', NSC Briefing, 19 May 1959, CIA-RDP79R00890A001100050023-5, CIA FOIA.

${ }^{27}$ For details of CIA operations undertaken in Kerala to destabilise the CPI government see, Ellsworth Bunker, Oral History, 18 June \& 17 Jul. 1979, Butler Library, Columbia University. See also, Howard B. Schaffer, Ellsworth Bunker: Global Troubleshooter, Vietnam Hawk (Chapel Hill: The University of South Carolina Press, 2003), 67.

${ }^{28}$ The evolution of Indo-U.S. relations under Eisenhower and Kennedy has received significant scholarly attention. See, for example, Paul M. McGarr, The Cold War in South Asia: Britain, the United States and the Indian Subcontinent, 1945-1965 (Cambridge: Cambridge University Press, 2013); Robert J. McMahon, The Cold War on the Periphery: The United States, India and Pakistan (New York: Columbia University Press, 1994); and Richard P. Dauer, A North-South Mind in an East-West World: Chester Bowles and the Making of United States Cold War Foreign Policy, 1951-1969 (Westport, CN:, Praeger, 2005).

${ }^{29}$ Vladislav Krasnov, Soviet Defectors: The KGB Wanted List (Stanford, CA: Hoover Institution Press, 1986), 116.

${ }^{30}$ George Blake, No Other Choice: An Autobiography (London: Jonathan Cape, 1990), 167.

${ }^{31}$ Stella Rimington, Open Secret: The Autobiography of the Former Director-General of MI5 (London: Arrow Books, 2002), 71-72.

${ }^{32}$ Ambassador Mary Seymour Olmsted, Oral History, 8 Apr.1992, Foreign Affairs Oral History Project, Library of Congress, Washington D.C., INTERNET, http://memory.loc.gov/ammem/collections/diplomacy/ (accessed February 7, 2013). For enlightening first-hand insights into CIA activity in India at the height of the Cold War, from an Agency officer that served in-country, see, Duane R. Clarridge, A Spy for All Seasons: My Life in the CIA (New York: Scribner, 1997), 76-78. For an alternative Indian Communist perspective on CIA operations in South Asia, real and imagined, see, L. Natarajan, American Shadow over India (New Delhi: People's Publishing House, 1956).

33 John Kenneth Galbraith, A Life in our Times: Memoirs (London: Andre Deutsch, 1981), 394-97.

${ }^{34}$ For broad context on the evolution of Indo-Soviet relations, see, Peter J. S. Duncan, The Soviet Union and India (London: Routledge, 1989); and Ramesh Thakur and Carlyle A. Thayer, Soviet Relations with India and Vietnam, 1945-1992 (New York: St. Martin's Press, 1992); and Vojtech Mastny, 'The Soviet Union's Partnership with India', Journal of Cold War Studies, (12, 3), (Summer 2010), 50-90.

${ }^{35}$ Andrew and Mitrokhin, The Mitrokhin Archive II, 9-10 and 312-14. See also, Jonathan Haslam, Russia's Cold War: From the October Revolution to the Fall of the Wall (Hew Haven, CT: Yale University Press, 2011), 154 and 156.

${ }^{36}$ Kalugin, Spymaster, 141.

${ }^{37}$ Quoted in Andrew, Defence of the Realm, 446.

38 'Soviet Program in India', NSC Briefing, 19 May 1959, CIA-RDP79R00890A001100050023-5, CIA FOIA.

39 T. V. Rajeswar, India: The Crucial Years (Noida, UP: Harper Collins India, 2015), 148.

${ }^{40}$ Harry Rositzke, The KGB: The Eyes of Russia (New York: Doubleday, 1981), 216-7.

41 'Sino-Soviet Bloc Propaganda Forgeries: 1 Jan. 1957 to 1 Jul. 1959', March 1960, CIA-RDP7802646R000300130001-0, CIA FOIA.

42 'Sino-Soviet Bloc Propaganda Forgeries', CIA FOIA.

${ }^{43}$ Robert Trumbull, 'Bowles Disavows a Pro-Red Letter', The New York Times, 1 Oct. 1952, 3.

${ }^{44}$ N. R. Patel to Jawaharlal Nehru, 'Action against Blitz for Miscellaneous Article', 2 May 1950, File No. 2/392, Private Papers of Sardar Patel [PSP], National Archives of India, New Delhi [NAI].

${ }^{45}$ See, 'Bowles in midst of Indian "Battle"', 2 Oct. 1952, 3.; 'Bowles' Note to Reds Was Faked', 17 Oct. 1952, 3; 'Indian Court Frees Editors in Forgery', 12 Nov. 1952, 5; '2 Indian Editors to Be Retried', 15 Nov. 1952, 3 ; 'Bowles Forgery Denied', The New York Times, 18 Feb. 1953, 12.

${ }^{46}$ I. C. Edwards to K. H. Cadbury, 7 Dec. 1956, [Kew, United Kingdom National Archives, Public Record Office], DO [Commonwealth Relations Office Records] 35/9524.

${ }^{47}$ Clarridge, Spy for All Seasons, 78.

48 'Clandestine Subversive Activities', CIA FOIA.

49 'Propaganda Forgeries, 1 Jan. 1957-1 Jul. 1959', CIA-RDP78-00915R001200060045-3, CIA FOIA.

50 'Clandestine Subversive Activities' CIA FOIA; W. J. Coe to A.C. Hall, 6 Jan. 1958, DO 35/9524.

51 'Sino-Soviet Bloc Propaganda Forgeries', CIA FOIA.

${ }^{52}$ Fryxell, 'Psywar By Forgery'.

${ }^{53}$ Richard Helms testimony to Senate Subcommittee to Investigate the Administration of the Internal Security Act, 2 Jun. 1961, (USGPO: Washington, DC, 1961).

${ }^{54}$ Richard Helms to Chief CA, 23 Sep. 1965, Electronic Reading Room, CIA-RDP80B01676R000100020003-8, CIA FOIA. 
55 'Reactions to Mr. Helms' Testimony on Communist Forgeries', 25 Aug. 1965, CIA-RDP7800915R001200060029-1, CIA FOIA.

${ }^{56}$ Chester Bowles, Promises to Keep: My Years in Public Life, 1941-1969 (New York, 1971), 544.

57 John Kenneth Galbraith, "CIA Needs a Tug on Its Purse Strings," The Washington Post, 12 Mar. 1967.

${ }^{58}$ Helms to Lyndon Johnson, 28 Mar. 1967, Box 9, Folder CIA Vol. 3 [1 of 2], N[ational] S[ecurity] F[ile], Lyndon Baines Johnson Library, Austin, Texas [LBJL]. See also, Hugh Wilford, The Mighty Wurlitzer: How the CIA Played America (Cambridge, Mass.: Harvard University Press, 2008), 241; and, Jeffreys-Jones, CIA and American Democracy, 162.

${ }^{59}$ John D. Smith, I Was a CIA Agent in India (New Delhi: New Age Printing Press, 1967). For details of IRD efforts to discredit Smith's pamphlet see, H. H. D Lancashire (New Delhi) to Cynthia Stephenson (IRD), 4 and 23 Jan. 1968, FCO 168/2649.

60 'India to Conduct Inquiry on C.I.A.,' The New York Times, Mar. 24, 1967; For an Indian communist perspective on the events of 1967 see, Pauly V. Parakal. CIA Dagger against India (New Delhi: New Age Press, 1973), 1416, and 53-58.

${ }^{61}$ For a detailed account of IRD operations in India, see, Paul M. McGarr, 'The Information Research Department, British Covert Propaganda, and the Sino-Indian War of 1962: Combating Communism and Courting Failure?' International History Review (41,1) (March 2019), 130-156.

${ }^{62}$ Tony Benn, Out of the Wilderness: Diaries 1963-67 (London: Hutchinson, 1987), 375-6. See also, J. P. Waterfield (New Delhi) to A. A. Duff (SAD, Commonwealth Office), 14 Aug. 1968, FCO 168/3215.

${ }^{63}$ C. F. R. 'Kit' Barclay minute, 22 Jun. 1966, FCO 168/2246.

${ }^{64}$ SLO Letter, undated and unsigned, c May 1962; N. M. Williamson (MI5) to J. L. Welser (IRD), 8 May 1962; and J. L. Welser (IRD) to N. M. Williamson (MI5), 10 May 1962, FCO 168/430.

${ }^{65}$ Freeman to Saville Garner, Apr. 11, 1967, FCO 95/200; "Brief Progress Report of IRD work in India, 1 Jan.30 Jun., 1967," FCO 95/290.

${ }^{66}$ J. P. Waterfield (New Delhi) to A.A. Duff (SAD, CO), 'The C.I.A. in India', 31 Mar. 1967, FCO 168/2649.

${ }^{67}$ John Freeman to Commonwealth office, 'Forgery of New Delhi Telegram', No. 282, 9 Feb. 1967, FCO $37 / 74$.

${ }^{68}$ J. P. Waterfield to A. A. Duff, 'Forgery of Delhi Telegram', 10 Feb. 1967, FCO 37/74.

${ }^{69}$ S. A. Lockhart to Mr. Joy, 10 Feb. 1967, FCO 37/74.

${ }^{70}$ Commonwealth office to New Delhi, 'Forgery of Delhi Telegram', No. 298, 10 Feb. 1967, FCO 37/74.

${ }^{71}$ Freeman to Commonwealth Office, 'Forgery', No. 303, 13 Feb. 1967, FCO 37/74.

${ }^{72}$ K. S. Bajpai, 'Note of conversation with Leonard Weiss, American Minister-Counsellor', 13 Feb. 1967, WII/104/7/67, Americas Division, M[inistry] of E[xternal] A[ffairs], NAI.

${ }^{73}$ A. A. Duff to Sir J, Johnston, 'Forgery of Delhi Telegram', 15 Feb. 1967, FCO 37/74.

${ }^{74}$ J. B. Johnston to Saville Garner, 16 Feb. 1967; P. Joy to Sydenham-Clarke, 16 Feb. 1967, FCO 37/74.

75 Saville Garner to J. B. Johnston, 17 Feb. 1967, FCO 37/74.

76 A. Raghavan, 'British worried over American aid to reaction', Blitz, 18 Feb. 1967.

77 American Embassy Report for the Ambassador, “Recent Clandestine Propaganda Activities', 17 Mar. 1967, copy lodged in WII/104/7/67, Americas Division, MEA, NAI.

${ }^{78}$ Freeman to Commonwealth Office, 'Forgery', No. 342, 18 Feb. 1967, FCO 37/74.

79 J. P. Waterfield to A. A. Duff, 'Forgeries', 2 Mar. 1967, FCO 37/74.

${ }^{80}$ American Embassy Report for the Ambassador, “Recent Clandestine Propaganda Activities', 17 Mar. 1967, copy lodged in WII/104/7/67, Americas Division, MEA, NAI.

81 Ibid.

82 R. McC. Samples minute, 'Forgery', 3 May 1967, FCO 37/74.

83 Tony Lukas, 'Anti-U.S. Forgery Reported in India', The New York Times, 6 May 1967.

${ }^{84}$ Galen Stone to Bowles, 'Recent Soviet Propaganda Broadcasts', 1 Sept. 1967, copy lodged in WII/104/7/67, Americas Division, MEA, NAI.

85 J. P. Waterfield to A. A. Duff, 'Forged Telegram', 15 Dec. 1967, FCO 37/74.

${ }^{86}$ Chester Bowles, 'Why Not Soviet-U.S. Cooperation in India?', American Reporter, 18 Dec. 1967.

${ }^{87}$ Bowles to Goldberg, 15 Jan. 1968, Box I-45, Folder 9 Issues India-Pakistan 1965-1967, LOCMD, Arthur J. Goldberg Papers [AJGP].

${ }^{88}$ Goldberg to Bowles, 23 Jan. 1968, Box I-45, Folder 9 Issues India-Pakistan 1965-1967, AJGP.

${ }^{89}$ Indian Embassy (Moscow) Political Report for Dec. 1967, 9 Jan. 1968, Monthly Political Reports (Other than Annual) from Embassy of India, Moscow, File No. HI/1012(57)/67, R\&I, MEA, NAI.

${ }^{90}$ H.H.D. Lancashire to J. G. McMinnies, 'Forgeries', 24 Jan. 1968, FCO 37/74.

91 'Did KGB Man Forge Freeman Telegram?', Young India, pp. 11-13, Jan. 1968.

${ }^{92}$ Rusk to New Delhi, 18 March 1968, and Bowles to Rusk, 19 Mar. 1968, (US cables shared with British), FCO $37 / 74$.

93 'Foe of Gandhi Stung by Accusations of C.I.A. Role', The New York Times, 19 Nov. 1989.

94 'Moynihan Assails India - C.I.A. charge,' The New York Times, 21 Nov. 1989. 
${ }^{95}$ Peter Joy minute, 10 Aug. 1967, FCO 168/2826.

${ }^{96}$ P. H. Roberts to Miss Holden, 'Foreign money in India', 23 Apr. 1976, FCO 37/1721.

97 'Soviet “Active Measures": Forgery, Disinformation, Political Operations', Special Report No. 88, Oct. 1981, United States Department of State, Bureau of Public Affairs.

${ }^{98}$ Peter Robert (New Delhi) to Cynthia Stephenson (IRD), 12 Sep.1968, FCO 168/3215.

${ }^{99}$ Richard Crossman, The Diaries of a Cabinet Minister, Vol. Three: Secretary of State for Social Services, 19681970 (London: Jonathan Cape, 1977), 166. 